\title{
Sinter-Joining of Ceramic to Graphite Using Vibratory Hot Press
}

\author{
By \\ Yoshiharu OZAKI and Shinroku SAITO \\ (Research Laboratory of Engineering Materials, Tokyo Institute of Technology)
}

振動ホットプレスによるセラミックーグラファイトの焼結接合

尾崎義治・斎藤進六

(東京工業大学 工業材料研究所)

It is well known that the sintering of oxides, of metals and of other substancs occures several handred degrees below the melting point of the lowest melting component. During the sintering process, evaporation-condensation, surface diffusion, volume diffusion, viscous flow and plastic deformation are taken place in a sintering body.

In current ceramic sinter-joining techniques, a suitable filler is used between the surface of two sintered bodies in order to make a good contact. In this joining technique, material transfers by diffusion are important.

On the other hand, at present joining technique using vibratory hot-pressing a ceramic powder was sintered and simultaneously joined to a graphite body, and in this case viscous flow and plastic deformation have important role.

It is the purpose of this paper to describe the new joining technique using vibratory hot-press,

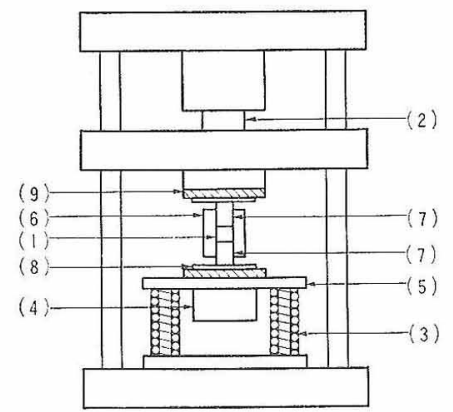

1) ceramic powder

6) graphite mold

2) hydraulic ram

3) spring

4) out-of-balanced motor

7) graphite punch

5) bottom punch plate

8) $\mathrm{Cu}$ electrode (water cooled)

9) alumina insulation plate

Fig. 1. The schematic layout of a vibratory hot-press apparatus. and examples for the ceramic to graphite joining are also shown photographically.

The schematic layout of the vibratory hot press design used in this investigations is shown in Fig. 1.

The ceramic powder (1) was compressed by the hydraulic ram (2) at a fixed pressure, through four springs (3) which transmitted the vibration. The

Table 1. Components of sample powders.

\begin{tabular}{lcc|c}
\hline & Powder A & Powder B & Powder C \\
\hline $\mathrm{Al}_{2} \mathrm{O}_{3}$ & 28.70 wt $\%$ & $91.48 w t \%$ & \\
$\mathrm{SiO}_{2}$ & 67.39 & 6.07 & 77 wt $\%-$ \\
$\mathrm{Fe}_{2} \mathrm{O}_{3}$ & 0.52 & 0.27 & powder $\mathrm{A}$ \\
$\mathrm{CaO}$ & 1.36 & 0.17 & + \\
$\mathrm{MgO}$ & $\mathrm{tr}$ & 1.39 & 23 wt $\%-$ \\
$\mathrm{Na}_{2} \mathrm{O}$ & 0.74 & 0.25 & graphite \\
$\mathrm{K}_{2} \mathrm{O}$ & 1.28 & 0.06 & \\
\hline
\end{tabular}
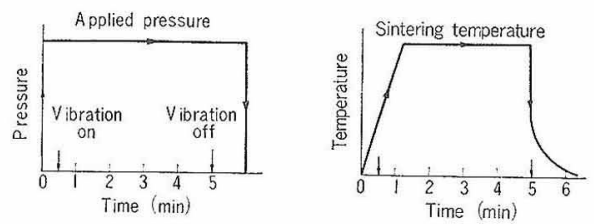

Fig. 2. Pressure and temperature diagram during vibratory hot-pressing.

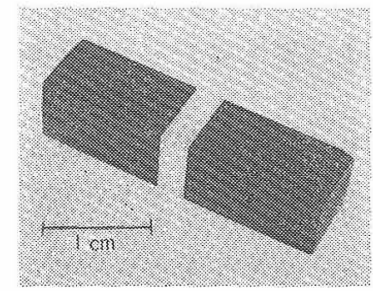

sample : powder A

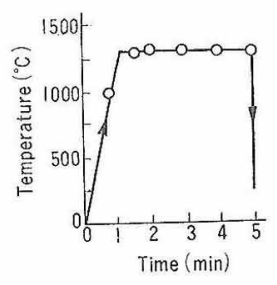

sintered at $1320^{\circ} \mathrm{C}$ pressure $60 \mathrm{~kg} / \mathrm{cm}^{2}$
Fig. 3. A sample of a sinter-joined alumina ceramic. 


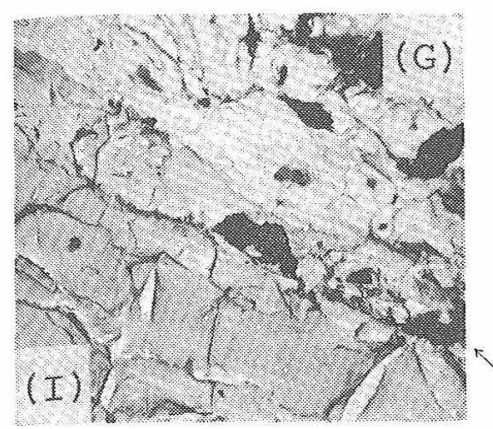

powder A sintered at $1320^{\circ} \mathrm{C}$

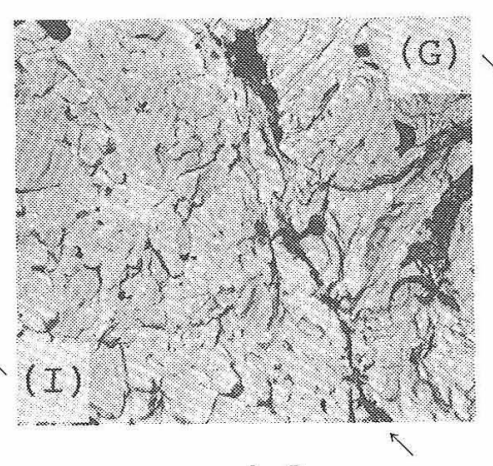

powder B sintered at $1450^{\circ} \mathrm{C}$

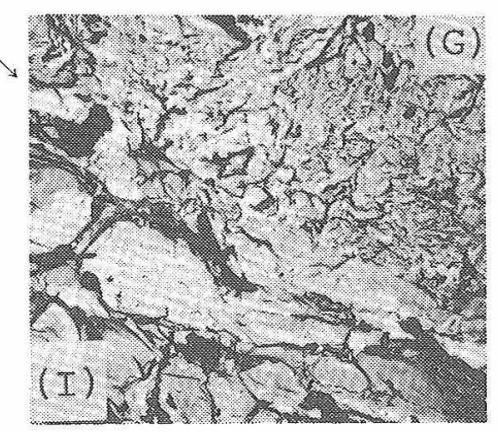

powder C sintered at $1350^{\circ} \mathrm{C}$

Fig. 4. Electron-micrographs of the sinter-joined contact parts (pressure $: 60 \mathrm{~kg} / \mathrm{cm}^{2}$, vibration time $: 4.5 \mathrm{~min}$ )

vibration was generated by the out-of-balanced motor (4) which was attached to a bottom punch plate (5). The frequency of vibration was only $60 \mathrm{c} / \mathrm{s}$. The graphite mold (6) was heated by resistance heating ${ }^{1}$. Two graphite punches (7) served as electrodes and joint bases.

Three different ceramic powders were used in this investigation, and which were shown in Table 1. All three ceramic powders were joined by the same procedure which was shown in Fig. 2 .

Fig. 3 shows an example of the sinter-joined powder A to graphite component and a joining condition. Electron micrographs of the contact parts between ceramic (I) and graphite (G) are shown in Fig. 4. Arrows show the joined surface boundaries. Apparently the existence of the stirred and mixed regions in the graphite bodies suggests that the strong joint of ceramic and graphite was accomplished by the forced viscous and/or plastic flow due to compression and vibration at high temperatures.

The bending strength of joint was stronger than that of graphite which is low bending strength component $\left(350 \mathrm{~kg} / \mathrm{cm}^{2}\right)$.

\section{References}

1) T. Suzuki and S. Saito, Powder and Powder Metallurgy 18, 28 (1971).

[Received July 24, 1972] 